\title{
Growth and Reproduction of Perionyx excavatus (Perrier) During Vermicomposting of Different Plant Residues
}

\author{
S. Debnath and P. S. Chaudhuri†
}

Department of Zoology, Tripura University (A Central University), Suryamaninagar-799022, Tripura (West), India †Corresponding author: P. S. Chaudhuri; priya_1956@rediffmail.com

Nat. Env. \& Poll. Tech. Website: www.neptjournal.com

Received: $18-02-2020$

Revised: $02-03-2020$

Accepted: 15-04-2020

Key Words:

Perionyx excavatus

Vermicomposting

Mass culture

Plant residues

\section{ABSTRACT}

The data on growth and reproduction of composting earthworms may be beneficial for large scale earthworm production. The growth and reproduction of Perionyx excavatus were assessed in limited supplies of four experimental diets-cow dung alone and its mixture with acacia (Acacia auriculiformis) leaf litter, bamboo (Bambusa polymorpha) leaf litter and terrestrial weed Mikania micrantha under laboratory conditions to select suitable diet from our locally available resource for vermiculture. Growth performance of Perionyx excavatus was significantly $(\mathrm{P}<0.05)$ higher in cow dung (maximum weight $\mathrm{mg} \mathrm{worm}^{-1} 629$ and growth rate $\mathrm{mg} \mathrm{worm}^{-1}$ day $\left.^{-1} 22.91\right)$. The rate of reproduction $\left(0.3\right.$ cocoons worm ${ }^{-1}$ day $^{-1}$ and 3.31 juveniles adult $^{-1}$ week $\left.^{-1}\right)$ was significantly higher $(\mathrm{P}<0.05)$ in acacia-cow dung mixture. The cocoon production was maximum on the $30^{\text {th }}$ day in all experimental diets (cow dung, acaciacow dung, bamboo-cow dung, mikania-cow dung). All the diets showed a maximum peak of juvenile production on the $45^{\text {th }}$ day. The lowest rate of biomass increase as well as the rate of reproduction were observed in mikania-cow dung mixture. Present result indicates that cow dung and acacia leaf litter can be used as vermiculture substrate for $P$. excavatus.

\section{INTRODUCTION}

Vermicomposting is the process of conversion of organic wastes into organic manure called vermicompost through the joint activities of epigeic earthworms and microorganisms. Selection of earthworm species for vermicomposting technology is mainly based on their reproductive potential, growth rate, the range of tolerance to ecological factors and nutrient contents of organic wastes etc. (Hallatt et al. 1992, Reinecke et al. 1992, Singh 2006, Suthar \& Ram 2008). Growth and reproduction of Eisenia fetida and Eudrilus eugeniae have been investigated by various workers (Suthar \& Ram 2008, Edwards et al. 1998, Gunadi \& Edwards 2003, Garg et al. 2005). Besides earthworm species such as Perionyx sensibaricus, Perionyx bainii, Perionyx ceylanensis and Perionyx nainianous have been tested for degradation of organic wastes (Julka et al. 2009). Animal dung (cattle, sheep, horse) have been widely used as vermiculture substrates (Edwards et al. 1998). Other vermiculture substrates include organic wastes from industry such as spent brewery yeast (Butt 1993) and agricultural wastes such as roots of barley (Bostrom \& Holmin 1986), ground corn (Zea mays) residue (Cook \& Linden 1996) and alfalfa leaves (Shipitalo et al. 1988). Native epigeic species Perionyx excavatus is a potential candidate for the conversion of organic wastes into useful plant growth media (Edwards et al. 1998, Kale et al. 1982, Chaudhuri 2005). Based on the above facts we aimed to investigate the effects of some locally available organic wastes such as terrestrial weed, Mikania micrantha, leaf litter of Acacia auriculiformis, leaf litter of Bambusa polymorpha mixed with cow dung on the growth and reproduction of oriental epigeic earthworm species, Perionyx excavatus in mass culture. The data on growth and reproduction of native species Perionyx excavatus may be useful to design vermiculture for large scale production of earthworms using different waste residues. It is mentionable that earthworms are used as fish baits worldwide and earthworm tissue is a good source of protein (vermitin) for poultry, pig and aquarium (Lowe \& Butt 2005).

\section{MATERIALS AND METHODS}

A study on growth and reproduction of Indian vermicomposting earthworm, Perionyx excavatus was carried out in a well-aerated room on four different diets such as cow dung (C), cow dung mixed with terrestrial climbing weed, Mikania micrantha (M) (often found to form hazardous bush around the roadside lamp posts forming shades against the light in Tripura), leaf litter of Acacia auriculiformis (A) and bamboo (Bambusa polymorpha) (B). Urine free cow dung, $M$. micrantha, leaf litter of Acacia and Bambusa were collected from Tripura University campus and its neighbouring areas. The leaf litter and plant biomass of M. micrantha were air- 
dried. The air-dried plant substrates were crushed to get small fractions. Four vermicomposting treatments were established by using earthen pot $(2.5 \mathrm{~L}$ capacity, diameter $25 \mathrm{~cm}$ and depth $15 \mathrm{~cm}$ ) having $300 \mathrm{~g}$ of dry feed mixtures in each pot. One treatment contained only C (300 g) as control and rest three experimental treatments were prepared by mixing the different plant substrates (A, B and $\mathrm{M}$ ) with $\mathrm{C}$ in $7: 3$ ratios (dry weight), i.e. $210 \mathrm{~g} \mathrm{~A}$ and $90 \mathrm{~g} \mathrm{C}$ (AC) in 7:3 ratio, $210 \mathrm{~g}$ $\mathrm{B}$ and $90 \mathrm{~g} \mathrm{C}(\mathrm{BC})$ in 7:3 ratio, $210 \mathrm{~g} \mathrm{M}$ and $90 \mathrm{~g} \mathrm{C}(\mathrm{MC})$ in $7: 3$ ratio. Before setting up the experiment, the authors made pilot studies using different ratios of $\mathrm{C}$ with weed $(\mathrm{M})$ and leaf litters (A and B) on a dry weight basis. It was observed that weeds (M) and leaf litter (A and B) Vs. C when mixed with $\mathrm{C}$ at 7:3 ratio, were suitable for earthworm inoculation and their subsequent activity. $P$. excavatus generally inhabits cow dung pits and prefers cow dung as its best food of choice compared to other diets. Each treatment had three replicas. Among these diets mixtures, AC was unpalatable to earthworms up to 21 days. So these feed mixtures (C, $\mathrm{AC}, \mathrm{BC}$, and MC) were pre-composted for 3 weeks to make palatable to earthworms. After pre-composting each culture pot of the four vermicomposting sets was inoculated with 30 adults of $P$. excavatus [cumulative weight $9.99 \pm 0.09 \mathrm{~g}$ (Mean $\pm \mathrm{SE}$ )]. The containers were covered tightly with jute cloth to prevent the escape of earthworms and entry of light inside. The taxonomic identification of the earthworm species was confirmed at Zoological Survey of India, Solan. The moisture content of the incubation media was maintained at 50 to $60 \%$ (Chaudhuri 2007) by using hand sprayer at maximum room temperature ranging in between $29^{\circ} \mathrm{C}$ to $31^{\circ} \mathrm{C}$. The earthworms were not supplied with additional food during 45 days experiment.

Cocoon and juvenile produced were collected fortnightly from the culture media with the aid of a hand lens. The live biomass of earthworms ( $\left.\mathrm{mg} \mathrm{worm}^{-1}\right)$, net weight gain $\left(\mathrm{mg} \mathrm{worm}^{-1}\right)$, growth rate $\left(\mathrm{mg}\right.$ worm ${ }^{-1}$ day $\left.^{-1}\right)$ and the rate of reproduction in terms of the cocoon (worm ${ }^{-1}$ day $^{-1}$ ) and juvenile generation (adult ${ }^{-1}$ week $^{-1}$ ) were measured at 15 days interval by hand sorting of the culture media. The rate of growth (mg worm $\left.{ }^{-1} \mathrm{day}^{-1}\right)$, the rate of cocoon production $\left(\right.$ worm $^{-1}$ day $^{-1}$ ) and rate of juvenile production (adult ${ }^{-1}$ week $^{-1}$ ) were calculated by the following formulae-

i. Rate of growth $\left(\mathrm{mg} \mathrm{worm}^{-1} \mathrm{day}^{-1}\right)=\frac{\text { Maximum worm weight }- \text { Initial worm weight }}{\text { No. of days to attain maximum weight }}$

ii. Rate of cocoon production (worm ${ }^{-1}$ day $^{-1}$ )

Maximum number of cocoons

$=\frac{\text { No. of adult at ' } 0 \text { ' day } \times \text { Total number of days to attain maximum number of cocoons }}{\text { nom }}$

iii. Rate of juvenile production (adult ${ }^{-1}$ week $^{-1}$ )

$$
=\frac{\text { Maximum number of juveniles }}{\text { No. of adult at ' } 0 \text { 'day } \times \text { Total number of days to attain the maximum number of juvenile population }} \times 7
$$

Initial substrates materials were analysed for $\mathrm{pH}(1: 2.5$ suspensions of the material and distilled water), electrical conductivity (distilled water suspension of each waste mixture in the ratio of $1: 10(\mathrm{~W} / \mathrm{V})$, total carbon (Walkley \& Black 1934), total Nitrogen (Jackson 1975), available phosphorus (Kuo 1996) and available potassium (Jones 2001). The data were subjected for analysis of variance (ANOVA) followed by Tukey's post hoc test using OriginPro 2016. All the results reported in the text are the mean of three replicates.

\section{RESULTS}

Table 1 shows the composition of food substrates provide to earthworms. The $\mathrm{pH}$ values of the food substrates were alkaline side of neutral (6.3 - 7.63). The highest electrical conductivity $(990 \mu \mathrm{Mho} / \mathrm{cm})$, nitrogen $(3.08 \%)$, available phosphorus $(163.71 \mathrm{mg} / 100 \mathrm{~g})$ and available potassium (7321.33 mg/100g) was recorded in MC. The maximum carbon content $(20.37 \%)$ was in MC and minimum (17.14\%) was in $\mathrm{C}$.

The differential growth $\left(\mathrm{mg}\right.$ worm $\left.{ }^{-1}\right)$ response of $P$. excavatus on various experimental diets over a period of 45 days is represented in Fig. 1. P. excavatus had the highest individual live weight $\left(629 \mathrm{mg} \mathrm{worm}^{-1}\right)$ in $\mathrm{C}$ with a net weight gain of $296.18 \mathrm{mg}$ worm ${ }^{-1}$ and growth rate of 22.91 $\mathrm{mg} \mathrm{worm}^{-1}$ day $^{-1}$ (Table 2). In fact, maximum weight gain, net weight gain and growth rate were significantly higher $(\mathrm{P}<0.05)$ in $\mathrm{C}$ compared to the other diets (Table 2). Highest growth rate (worm ${ }^{-1} \mathrm{day}^{-1}$ ) in $\mathrm{C}$ was followed by that in $\mathrm{BC}, \mathrm{MC}$, and $\mathrm{AC}$. In AC, lowest net weight gain (52.02 $\left.\mathrm{mg} \mathrm{worm}^{-1}\right)$ and lowest growth rate $\left(3.47 \mathrm{mg} \mathrm{worm}^{-1}\right.$ day $\left.^{-1}\right)$ were recorded. $P$. excavatus had early biomass gain in $\mathrm{C}$, $\mathrm{BC}$, and $\mathrm{AC}$ on the $15^{\text {th }}$ day, whereas the highest individual biomass was achieved on the $30^{\text {th }}$ day in MC (Table 2). After attaining highest biomass a gradual decline was observed up 


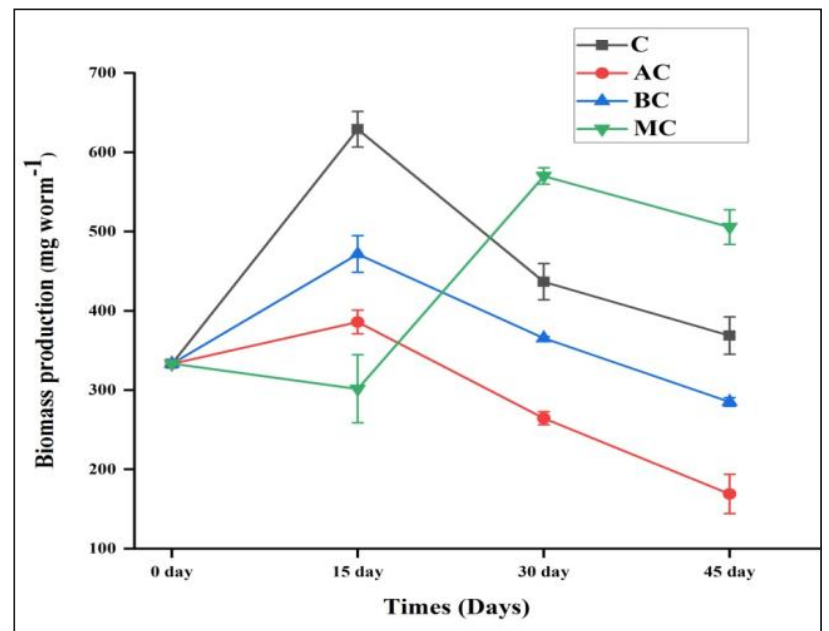

Fig. 1: Changes in biomass production of $P$. excavatus in different experimental diets; Abbreviation: C- cow dung, AC- acacia-cow dung, $\mathrm{BC}$ - bamboo- cow dung, MC- mikania- cow dung.

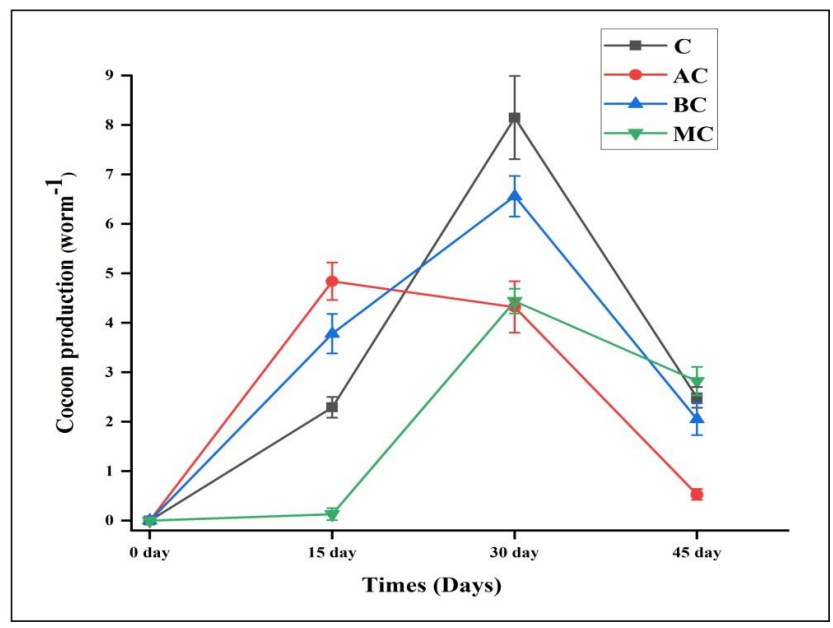

Fig. 2:Dynamics of cocoons production of $P$. excavatus in different experimental diets; Abbreviation: C- cow dung, AC- acacia-cow dung, $\mathrm{BC}$ - bamboo- cow dung, MC- mikania- cow dung.

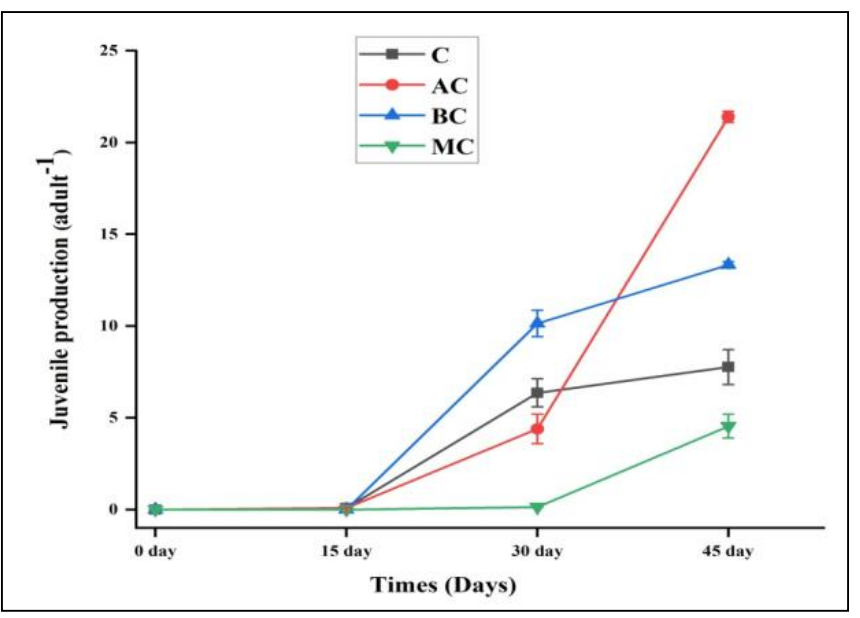

Fig. 3: Patterns juveniles production of P. excavatus in different experimental diets; Abbreviation: C- cow dung, AC- acacia-cow dung, BC- bamboo- cow dung, MC- mikania- cow dung.

Table 1: Some analytical characteristics of experimental diets (Mean $\pm \mathrm{SE})$.

\begin{tabular}{|lllll|}
\hline & $\mathrm{C}$ & AC & BC & MC \\
\hline $\mathrm{pH}$ & $7.42 \pm 0.14$ & $6.3 \pm 0.005$ & $6.75 \pm 0.003$ & $7.63 \pm 0.11$ \\
\hline Electrical Conductivity $(\mu \mathrm{Mho} / \mathrm{cm})$ & $580.66 \pm 0.66$ & $570 \pm 0.00$ & $720 \pm 0.00$ & $990 \pm 0.01$ \\
\hline Organic Carbon $(\%)$ & $17.14 \pm 0.58$ & $19.83 \pm 0.04$ & $19.52 \pm 0.76$ & $20.37 \pm 0.54$ \\
\hline Available Phosphorus $(\mathrm{mg} / 100 \mathrm{~g})$ & $147.39 \pm 5.08$ & $26.15 \pm 0.17$ & $48.97 \pm 0.8$ & $163.71 \pm 2.5$ \\
\hline Available Potassium $(\mathrm{mg} / 100 \mathrm{~g})$ & $1000 \pm 14.43$ & $1087 \pm 7.21$ & $937.33 \pm 7.21$ & $7321.33 \pm 14.2$ \\
\hline Total Nitrogen $(\%)$ & $1.26 \pm 0.006$ & $1.82 \pm 0.003$ & $1.62 \pm 0.003$ & $3.08 \pm 0.05$ \\
\hline
\end{tabular}

Abbreviation: C- cow dung, AC- acacia-cow dung, BC- bamboo- cow dung, MC- mikania-cow dung.

to 45 days in all diets (Fig. 1). At the end of the experiment, the maximum mean biomass of $P$. excavatus was achieved in $\mathrm{MC}$ followed by those in $\mathrm{C}, \mathrm{BC}$, and $\mathrm{AC}$ (Fig. 1).
The reproduction potential of $P$. excavatus in terms of their cocoon production (worm ${ }^{-1} \mathrm{day}^{-1}$ ) and juvenile production $\left(\right.$ worm $^{-1}$ week $^{-1}$ ) among different experimental diets are 
summarized in Table $3(\mathrm{a}, \mathrm{b})$. The rate of cocoon production was highest $(\mathrm{P}<0.05)$ in $\mathrm{AC}$ followed by $\mathrm{C}, \mathrm{BC}$ and least in MC (Table 3a). P. excavatus had an earlier peak of cocoon production (4.84 worm $^{-1}$ ) on the $15^{\text {th }}$ day in AC (Fig. 2). However, cocoon production (worm ${ }^{-1}$ ) in general was highest in all the experimental diets on the $30^{\text {th }}$ day (Fig. 2). The cocoon production was ceased after $30^{\text {th }}$ day in all experimental diets (Fig. 2). The rate of juvenile production (adult ${ }^{-1}$ week $\left.^{-1}\right)$ also differed $(\mathrm{P}<0.05)$ among the four different food substrates (Table $3 \mathrm{~b}$ ). All the treatments (C, AC, $\mathrm{BC}$, and $\mathrm{MC}$ ) showed a maximum peak of juvenile production on the $45^{\text {th }}$ day (Fig. 3) i.e. 15 days after the peak of cocoon production (Fig. 2). The appearance of the juveniles was first encountered in $\mathrm{C}$ and $\mathrm{AC}$ (i.e. on the $15^{\text {th }}$ day) and later in $\mathrm{BC}$ and $\mathrm{MC}$ (i.e. $30^{\text {th }}$ day) (Table $3 \mathrm{~b}$ ). The highest number (total number) and rate of juvenile production (adult ${ }^{-1}$ week ${ }^{-1}$ ) were on the $45^{\text {th }}$ day and were in the following order $\mathrm{AC}>\mathrm{BC}>\mathrm{C}>\mathrm{MC}$ (Fig. 3). Growth and reproduction rate of some epigeic earthworm species are given in Table 4.

\section{DISCUSSION}

The palatability of earthworms for organic wastes is influenced by its physico-chemical characteristics and nutrient contents that affect the efficiency of earthworms in the decomposition process and their growth in the organic wastes (Chaudhuri 2002, Suthar 2007a). Individual live weight $\left(629 \mathrm{mg} \mathrm{worm}^{-1}\right)$, growth rate $\left(22.91 \mathrm{mg} \mathrm{worm}^{-1}\right.$ day $\left.^{-1}\right)$ and net weight gain $\left(296.18 \mathrm{mg} \mathrm{worm}^{-1}\right)$ of $P$. excavatus, were maximum in $\mathrm{C}$. The highest growth rate of $P$. excavatus in $\mathrm{C}$ was because a minimum of only 15 days was required to attain its highest biomass and net weight gain. According to Loh et al. (2005) cow dung is a most preferred diet of earthworms irrespective of the species which could be due to easily assimilable organic matter and presence of low growth retarding factors in it (Suthar 2007a). Maximum individual biomass of $P$. excavatus $\left(600 \mathrm{mg}\right.$ worm $\left.^{-1}\right)$ in animal dung was reported by Hallat et al. (1990) supports our observation of maximum mean individual live weight of $P$. excavatus $(629$ $\mathrm{mg} \mathrm{worm}^{-1}$ on the $15^{\text {th }}$ day) in C. Nitrogen-rich diets promote

Table 2: Growth of P. excavatus in different experimental diets (Mean $\pm \mathrm{SE}$ ).

\begin{tabular}{|llllll|}
\hline Substrates & $\begin{array}{l}\text { Mean initial weight } \\
\left(\mathrm{mg} \mathrm{worm}^{-1}\right)\end{array}$ & $\begin{array}{l}\text { Mean maximum } \\
\text { weight }\left(\mathrm{mg} \mathrm{worm}^{-1}\right)\end{array}$ & $\begin{array}{l}\text { Maximum weight } \\
\text { achieved on }\end{array}$ & $\begin{array}{l}\text { Net weight gain } \\
\left(\mathrm{mg} \mathrm{worm}^{-1}\right)\end{array}$ & $\begin{array}{l}\text { Growth rate } \\
\left(\mathrm{mg} \mathrm{worm}^{-1} \text { day }^{-1}\right)\end{array}$ \\
\hline C & $333.31 \pm 0.12^{\mathrm{a}}$ & $629 \pm 22.31^{\mathrm{a}}$ & $15^{\text {th }}$ day & $296.18 \pm 23.11^{\mathrm{a}}$ & $22.91 \pm 1.93^{\mathrm{a}}$ \\
AC & $333.33 \pm 0.30^{\mathrm{a}}$ & $385.86 \pm 14.87^{\mathrm{b}}$ & $15^{\text {th }}$ day & $52.02 \pm 0.84^{\mathrm{b}}$ & $3.47 \pm 0.99^{\mathrm{b}}$ \\
BC & $333.3 \pm 0.1^{\mathrm{a}}$ & $471.52 \pm 23.18^{\mathrm{c}}$ & $15^{\text {th }}$ day & $138.18 \pm 23.18^{\mathrm{c}}$ & $12.6 \pm 1.54^{\mathrm{c}}$ \\
MC & $333.37 \pm 0.36^{\mathrm{a}}$ & $570 \pm 10.32^{\mathrm{d}}$ & $30^{\text {th }}$ day & $236.66 \pm 20.2^{\mathrm{d}}$ & $9.47 \pm 1.13^{\mathrm{d}}$ \\
\hline
\end{tabular}

Abbreviation: C- cow dung, AC- acacia-cow dung, BC- bamboo- cow dung, MC- mikania- cow dung.

Different letters correspond to a significant difference $(\mathrm{P}<0.05)$.

Table 3: Rate of reproduction of $P$. excavatus in differential experimental diets (Mean $\pm \mathrm{SE})$.

(a) Cocoons production of $P$. excavatus in different experimental diets.

\begin{tabular}{|lllll|}
\hline Substrates & $\begin{array}{l}\text { Cocoon production } \\
\text { started in }\end{array}$ & $\begin{array}{l}\text { Total no. of cocoons produced after } \\
45 \text { days }\end{array}$ & $\begin{array}{l}\text { No. of cocoons } \\
\text { produced }\left(\text { worm }^{-1}\right)\end{array}$ & $\begin{array}{l}\text { Rate of cocoon production } \\
\left(\text { worm }^{-1} \text { day }^{-1}\right)\end{array}$ \\
\hline C & $15^{\text {th }}$ day & $205 \pm 32.5^{\mathrm{a}}$ & $6.84 \pm 0.9^{\mathrm{a}}$ & $0.25 \pm 0.008^{\mathrm{a}}$ \\
AC & $15^{\text {th }}$ day & $107 \pm 22.8^{\mathrm{b}}$ & $3.05 \pm 0.7^{\mathrm{b}}$ & $0.3 \pm 0.25^{\mathrm{b}}$ \\
BC & $15^{\text {th }}$ day & $136 \pm 21.9^{\mathrm{b}}$ & $3.9 \pm 0.6^{\mathrm{b}}$ & $0.23 \pm 0.11^{\mathrm{a}}$ \\
MC & $15^{\text {th }}$ day & $81 \pm 21.3^{\mathrm{c}}$ & $2.2 \pm 0.6^{\mathrm{c}}$ & $0.13 \pm 0.01^{\mathrm{c}}$ \\
\hline
\end{tabular}

(b) Juveniles production from the cocoons of P. excavatus.

\begin{tabular}{|c|c|c|c|}
\hline Substrates & Emergence of juveniles on & Total no. of juvenile production after 45 days & Rate of juvenile production (adult ${ }^{-1}$ week $^{-1}$ ) \\
\hline $\mathrm{C}$ & $15^{\text {th }}$ day & $156 \pm 39.5^{\mathrm{a}}$ & $1.39 \pm 0.07^{\mathrm{a}}$ \\
\hline $\mathrm{AC}$ & $15^{\text {th }}$ day & $284 \pm 23.2^{\mathrm{b}}$ & $3.31 \pm 0.03^{\mathrm{b}}$ \\
\hline $\mathrm{BC}$ & $30^{\text {th }}$ day & $387 \pm 23.8^{\mathrm{c}}$ & $2.22 \pm 0.027^{\mathrm{c}}$ \\
\hline $\mathrm{MC}$ & $30^{\text {th }}$ day & $78 \pm 10.2^{\mathrm{d}}$ & $0.66 \pm 0.11^{\mathrm{d}}$ \\
\hline
\end{tabular}

Abbreviation: C- cow dung, AC- acacia-cow dung, BC- bamboo- cow dung, MC- mikania- cow dung.

Different letters correspond to a significant difference $(\mathrm{P}<0.05)$. 
Table 4: Growth and reproduction rate in some epigeic earthworm species.

\begin{tabular}{|c|c|c|c|c|c|}
\hline \multirow{2}{*}{$\begin{array}{l}\text { Earthworm } \\
\text { species }\end{array}$} & \multirow[t]{2}{*}{ Culture materials } & \multirow{2}{*}{$\begin{array}{l}\text { Growth rate } \\
\left(\mathrm{mg} \mathrm{worm}^{-1}\right. \\
\left.\text { day }^{-1}\right)\end{array}$} & \multicolumn{2}{|c|}{ Reproduction rate } & \multirow{2}{*}{ References } \\
\hline & & & $\begin{array}{l}\text { Cocoon } \\
\left.\text { (worm }^{-1} \text { day }^{-1}\right)\end{array}$ & $\begin{array}{l}\text { Juvenile } \\
\left(\text { adult }^{-1} \text { week }^{-1}\right)\end{array}$ & \\
\hline \multirow{10}{*}{$\begin{array}{l}\text { Perionyx } \\
\text { excavatus }\end{array}$} & Cowdung & 22.91 & 0.25 & 1.39 & Present study \\
\hline & Acacia leaf litter- Cowdung & 3.47 & 0.3 & 3.31 & Present study \\
\hline & Bamboo leaf litter- Cowdung & 12.6 & 0.23 & 2.22 & Present study \\
\hline & Mikania micrantha-Cowdung & 9.47 & 0.13 & 0.66 & Present study \\
\hline & Cowdung & 2.86 & - & 2.45 & Chaudhuri \& Bhattacharjee (2002) \\
\hline & Cowdung-Kitchen wastes & 2.47 & - & 1.37 & Chaudhuri \& Bhattacharjee (2002) \\
\hline & Cowdung- Straw & 4.75 & - & 14 & Chaudhuri \& Bhattacharjee (2002) \\
\hline & Cowdung- Leaf litter & 4.02 & - & 11.7 & Chaudhuri \& Bhattacharjee (2002) \\
\hline & Rubber leaf litter & 5.04 & - & 0.2 & Chaudhuri et al. (2003) \\
\hline & Pressmud-Cowdung & 4.81 & 0.79 & - & Birundha et al. (2013) \\
\hline $\begin{array}{l}\text { Perionyx } \\
\text { ceylanensis }\end{array}$ & Cowdung & 1.34 & 0.94 & - & Karmegam \& Daniel (2009) \\
\hline \multirow[t]{2}{*}{$\begin{array}{l}\text { Perionyx } \\
\text { sansibaricus }\end{array}$} & $\begin{array}{l}\text { Kitchen waste- Mangifera indica } \\
\text { leaf litter }\end{array}$ & 3.77 & 0.25 & - & Suthar (2007a) \\
\hline & Cattle solid wastes & 8.00 & 0.22 & - & Suthar (2009) \\
\hline \multirow[t]{4}{*}{ Eisenia fetida } & Cowdung & 16.3 & 0.39 & - & Garg et al. (2005) \\
\hline & Goat waste & 16.5 & 0.32 & - & Garg et al. (2005) \\
\hline & Sheep wastes & 26.2 & 0.44 & - & Garg et al. (2005) \\
\hline & Rubber leaf litter & 6.2 & - & 1.3 & Chaudhuri et al. (2003) \\
\hline \multirow{2}{*}{$\begin{array}{l}\text { Eudrilus } \\
\text { eugeniae }\end{array}$} & Diospyrosa meanoxylon leaf litter & 68.00 & 0.54 & - & Kadam (2015) \\
\hline & Rubber leaf litter & 28.8 & - & 1.4 & Chaudhuri et al. (2003) \\
\hline $\begin{array}{l}\text { Lumbricus } \\
\text { rubellus }\end{array}$ & Cowdung & 8.02 & 0.77 & - & Elvira et al. (1996) \\
\hline $\begin{array}{l}\text { Dendrobaena } \\
\text { rubida }\end{array}$ & Cowdung & 3.84 & 0.2 & - & Elvira et al. (1996) \\
\hline $\begin{array}{l}\text { Dichogaster } \\
\text { modiglianii }\end{array}$ & Pasture soil & - & 0.19 & - & Bhattacharjee \& Chaudhuri (2002) \\
\hline
\end{tabular}

in rapid growth and reproduction in earthworms (Evans \& Guild 1948). Despite high nitrogen $(3.08 \mathrm{mg} / 100 \mathrm{~g})$ content in MC, $P$. excavatus showed a delay in the increase in biomass production in $\mathrm{MC}$, probably due to its high $\mathrm{pH}$ (7.63) and electrical conductivity $(990 \mu \mathrm{Mho} / \mathrm{cm})$. Presence of high content of soluble salts as indicated by the highest electrical conductivity in MC might harm earthworm feeding activity. Moreover, the antifungal and antimicrobial properties of essential oils of mikania (Baral et al. 2011) perhaps prevent the microflora to release the locked-up nutrients during the initial stage of waste decomposition. So during the first 15 days, earthworm growth was retarded in MC instead of a sudden rise as found in other diets. But with the progress of decomposition, those growth retarding substances in the wastes probably declined so that palatability and release of locked up nutrients gradually increased in MC at a later stage leading to highest weight gain by $P$. excavatus in MC on the $30^{\text {th }}$ day. Lowest growth rate $\left(3.47 \mathrm{mg}\right.$ worm $^{-1}$ day $\left.^{-1}\right)$ with lowest net weight gain $\left(52.02 \mathrm{mg}\right.$ worm $\left.^{-1}\right)$ of $P$. excavatus in the AC was probably due to high lignin and rich polyphenol content of Acacia that suppressed the growth rate of earthworms through their effects on their feeding activities (Ganesh et al. 2009). Polyphenol content in the leaf has an inverse relationship with the palatability of earthworms (Edwards \& Bohlen 1996). Low biomass values of earthworms under 3-10 years old rubber plantations due to excess flavonoid, lignin, and polyphenol contents of rubber leaves as reported by Chaudhuri et al. (2013) support our present findings. The growth rate of $P$. excavatus in different experimental diets $(\mathrm{C}, \mathrm{AC}, \mathrm{BC}$, and $\mathrm{MC})$ ranging in between $3.47 \mathrm{mg} \mathrm{worm}^{-1} \mathrm{day}^{-1}$ (AC) to $22.91 \mathrm{mg} \mathrm{worm}^{-1}$ day $^{-1}(\mathrm{C})$ is much higher than those of $P$. ceylanensis $(1.34-1.79 \mathrm{mg}$ 
worm $^{-1}$ day $^{-1}$ ) and the growth rate recorded for P. excavatus and $P$. sansibaricus by various workers that ranged from 3.5 to $8.0 \mathrm{mg} \mathrm{worm}^{-1}$ day $^{-1}$ (Reinecke et al. 1992, Suthar \& Ram 2008, Karmegam \& Daniel 2009, Suthar 2009) but lower than the growth rate of other vermicomposting species viz. E. eugeniae and E. fetida as mentioned in Table 4 (Garg et al. 2005, Kadam 2015).

Earthworms begin reproduction after attainment of a certain level of biomass (Chaudhuri et al. 2002). Thus, in all experimental diets (C, AC, BC and MC) following attainment of maximum biomass on the $15^{\text {th }}$ day, the highest level of cocoon production and juvenile production was observed on the $30^{\text {th }}$ day and $45^{\text {th }}$ day respectively. The reason behind the occurrence of the peak of cocoon production earlier than the juvenile production was because after a certain period of incubation (13-14 days development time) hatchlings were produced. Thus cocoon development time of 15 days and more than one hatchling emergence per cocoon (Bhattacharjee \& Chaudhuri 2002) were responsible for the dramatic rise in juvenile production on the $45^{\text {th }}$ day in all of the diets $(\mathrm{C}, \mathrm{AC}, \mathrm{BC}$, and $\mathrm{MC})$. Interestingly, despite lowest biomass and growth rate of $P$. excavatus in $\mathrm{AC}$, the rate of reproduction in terms of cocoon production $\left(0.3\right.$ worm $^{-1}$ day $^{-1}$ ) or juvenile production (3.31 adult ${ }^{-1}$ week $^{-1}$ ) in it was very high. The rate of reproduction in terms of cocoon production in AC was much higher than that in $P$. sansibaricus $\left(0.22\right.$ cocoon worm ${ }^{-1}$ day $^{-1}$ and 0.25 cocoon worm $^{-1}$ day $^{-1}$ ) reared in cattle solid wastes and kitchen waste mixed with $M$. indica leaf litter respectively (Table 4). High biomass value with a lower rate of reproduction of $P$. excavatus in the kitchen wastes was earlier recorded (Table 4). Thus a good biomass supporting medium may not be a good medium for reproduction (Haimi 1990, Dominguez et al. 1997). Besides, the biochemical qualities of the food substrates, microbial biomass, and decomposition activities are some of the important factors that determine the onset of cocoon production in earthworms (Dominguez et al. 2003, Suthar 2006). Thus high polyphenol and lignin-containing substrates which exerted negative impacts on the growth rate of earthworm, $P$. excavatus in AC were probably not the inhibitory factor for the reproduction of $P$. excavatus. Juvenile production (3.31 juvenile adult ${ }^{-1}$ week $^{-1}$ ) in $P$. excavatus cultured in $\mathrm{AC}$ is higher than that in E. fetida (1.3 juvenile adult ${ }^{-1}$ week $\left.^{-1}\right)$ and 1.4 juvenile adult $^{-1}$ week $^{-1}$ in E. eugeniae reared in rubber leaf litter (Chaudhuri et al. 2003) (Table 4). According to Suthar (2007b), the nitrogen content of the culture media has a positive effect on the rate of cocoon production in earthworms and their further development through influencing dietary need of protein. Despite having rich nitrogen contents $(3.08 \%)$ in MC, $P$. excavatus had the lowest rate of reproduction (rate of cocoon production 0.13 worm $^{-1}$ day $^{-1}$ and rate of juvenile production 0.66 adult $^{-1}$ week $^{-1}$ ) in MC. Microbial communities act as a good food source of earthworms (Suthar 2008). The rich content of phytochemicals along with various essential oil having antifungal and antimicrobial activities (Baral et al. 2011, Rufatto et al. 2012) probably inhibited the rate of reproduction of $P$. excavatus in $\mathrm{MC}$ at the initial stage of the experiment. For this reason, no juveniles were produced on the $15^{\text {th }}$ day and only a few juveniles $\left(0.14\right.$ adult $\left.^{-1}\right)$ appeared on the $30^{\text {th }}$ day in the MC. Suthar \& Sharma (2013) also reported a negative effect of high phytochemicals on the cocoon production of E. fetida. However, 0.66 juvenile generation adult ${ }^{-1}$ week $^{-1}$ in $P$. excavatus reared in MC was much lesser than 1.3 juvenile adult ${ }^{-1}$ week $^{-1}$ and 1.4 juvenile adult $^{-1}$ week $^{-1}$ in $E$. fetida and $E$. eugeniae cultured in rubber leaf litter (Table 4). The lowest rate of cocoon production by $P$. excavatus $\left(0.25\right.$ and 0.23 worm $^{-1}$ day $\left.^{-1}\right)$ despite having highest mean numbers of cocoons per worm in $\mathrm{C}(6.84)$ and $\mathrm{BC}\left(3.05\right.$ worm $\left.^{-1}\right)$ was since the time required to achieve the maximum number of cocoons were longer.

\section{CONCLUSION}

The present work was conducted to assess the growth and reproduction of $P$. excavatus during vermicomposting of cow dung and its mixture with different plant residues (leaf litter of Acacia auriculiformis, Bambusa polymorpha, Mikania micrantha) under laboratory conditions. Maximum biomass gain $(\mathrm{P}<0.05)$ and significantly higher $(\mathrm{P}<0.05)$ growth rate of $P$. excavatus were observed in cow dung. Reproduction performance (rate of cocoon production worm ${ }^{-1}$ day $^{-1}$ and juvenile production worm ${ }^{-1}$ week $^{-1}$ ) of $P$. excavatus was highest in $(\mathrm{P}<0.05)$ acacia- cow dung mixture. Thus it can be concluded from the present study that cow dung and acacia leaf litter can be used as vermiculture substrate for $P$. excavatus.

\section{ACKNOWLEDGMENT}

The authors express their gratefulness to DBT (Sanction Order No. BT/PR24972/NER/95/932/2017), New Delhi for funding the investigation and Dr. Niladri Paul, Assistant Professor, College of Agriculture, Lembucherra, Tripura for providing lab facilities to analyze the chemical parameters of the wastes materials.

\section{REFERENCES}

Baral, B., Bhattarai, N. and Vaidya, G.S. 2011. Pharmacological and antagonistic potentials of Mikania micrantha. Nepal J. Sci. Technol., 12: 75-84.

Bhattacharjee, G. and Chaudhuri, P.S. 2002. Cocoon production, morphology, hatching pattern and fecundity in seven tropical earthworm species-a laboratory-based investigation. J. Biosci., 27: 283-294. 
Birundha, M., Paul, J.A.J and Mariappan, P. 2013. Growth and reproduction of Perionyx excavatus in different organic wastes. Int. J. Curr. Microbiol. Appl. Sci., 2(2): 28-35.

Bostrom, U. and Lofs-Holmin, A. 1986. Growth of earthworms (Allolobophora caliginosa) fed shoots and roots of barley, meadow fescue and lucerne. Studies in relation to particle size, protein, crude fiber content and toxicity. Pedobiologia., 29: 1-12.

Butt, K.R. 1993. Utilisation of solid paper-mill sludge and spent brewery yeast as a feed for soil-dwelling earthworms. Bioresour. Technol., 44: 105-107.

Chaudhuri, P.S. and Bhattacharjee, G. 2002. Capacity of various experimental diets to support biomass and reproduction of Perionyx excavatus. Bioresour. Technol., 82: 147-150.

Chaudhuri, P.S., Pal, T.K, Bhattacharjee, G. and Dey, S.K. 2003. Rubber leaf litters (Hevea brasiliensis, var RRIM 600) as vermiculture substrate for epigeic earthworms, Perionyx excavatus, Eudrilus eugeniae and Eisenia fetida. Pedobiologia., 47: 796-800.

Chaudhuri, P.S. 2005. Vermiculture and vermicomposting as biotechnology for conversion of organic wastes into animal protein and organic fertilizer. Asian J. Microbiol. Biotechnol. Environ. Sci.,7: 359-370.

Chaudhuri, P.S. 2007. Vermicomposting as biotechnology for conversion of organic wastes into organic fertilizer and animal protein. In: Singh, S.M. (ed.) Earthworms for Solid Waste Management. International Book Distributing Co., Lucknow, pp. 75-88.

Chaudhuri, P.S., Bhattacharjee, S., Dey, A., Chattopadhyay, S. and Bhattacharya, D. 2013. Impact of age of rubber (Hevea brasiliensis) plantation on earthworm communities of West Tripura (India). J. Environ. Biol., 34: 59-65.

Cook, S.M.F. and Linden, D.R. 1996. Effect of food type and placement on earthworm (Aporrectodea tuberculata) burrowing and soil turnover. Biol. Fert. Soils., 21: 201-206.

Dominguez, J., Briones, M.J.I. and Mato, S. 1997. Effect of the diet on growth and reproduction of Eisenia andrei (Oligochaeta, Lumbricidae). Pedobiologia., 41(6): 566-576.

Dominguez, J., Parmelee, R.W. and Edwards, C.A. 2003. Interactions between Eisenia andrei (Oligochaeta) and nematode populations during vermicomposting. Pedobiologia., 47: 53-60.

Edwards, C.A. and Bohlen, P.J. 1996. Biology and Ecology of Earthworms. Chapman and Hall, London., pp. 426.

Edwards, C. A., Dominguez, J. and Neuhauser, E.F. 1998. Growth and reproduction of Perionyx excavatus (Perr.) (Megascolecidae) as factors in organic waste management. Biol. Fert. Soils., 27: 155-161.

Elvira, C., Dominguez, J. and Mato. S. 1996. The growth and reproduction of Lumbricus rubellus and Dendrobaena rubida in cow manure mixed cultures with Eisenia andrei. Appl. Soil. Ecol., 5: 97-103.

Evans, AC. and Guild, W.J.M. 1948. Studies on the relationships between earthworms and soil fertility. Ann. App. Biol., 35: 471-484.

Garg, V.K., Chand, S., Chhillar, A. and Yadav, A. 2005. Growth and reproduction of Eisenia foetida In various animal wastes during vermicomposting. App. Ecol. Env. Res., 3(2): 51-59.

Ganesh, P.S., Gajalakshmi, S. and Abbasi, S. 2009. Vermicomposting of the leaf litter of acacia (Acacia auriculiformis): Possible roles of reactor geometry, polyphenols, and lignin. Bioresour. Technol., 100: 1819-1827.

Gunadi, B. and Edwards, C.A. 2003. The effects of multiple applications of different organic wastes on the growth, fecundity and survival of Eisenia fetida (Savigny) (Lumbricidae). Pedobiologia., 47: 321-329.

Hallatt, L., Reinecke, A.J. and Viljoen, S.A. 1990. The life cycle of the oriental compost worm Perionyx excavatus (Oligochaeta). S. Afr. J. Zool., 25: 41-45.

Hallatt, L., Viljoen, S. and Reinecke, A. 1992. Moisture requirements in the life cycle of Perionyx excavatus (Oligochaeta). Soil Biol. Biochem., 24: $1333-1340$.

Haimi, J. 1990. Growth and reproduction of the compost-living earthworms
Eisenia andrei and E. fetida. Revue d'Ecologie et de Biologie du Sol., 27: 415-421.

Jackson, M.L. 1975. Soil Chemical Analysis. Prentice-Hall, New Delhi., pp.183-226.

Jones, J.B. 2001. Laboratory Guides for Conducting Soil Tests and Plant Analysis. CRC Press, Boca Raton., pp. 384.

Julka, J. M., Paliwal, R. and Kathireswari, P. 2009. Biodiversity of Indian earthworms - an overview. In: Edwards, C.A., Jayaraaj, R. and Jayraaj, I.A. (eds.) Proceedings of Indo-US Workshop on Vermitechnology in Human Welfare. Rohini Achagam, Coimbatore, India.

Kadam, D.G. 2015. Growth and reproduction of Eudrilus eugeniae in Tendu (Diospyros melanoxylon Roxb.) leaf residues as influenced by feed particle size. Int. J. Curr. Microbiol. Appl. Sci., 4: 206-210.

Kale, R.D., Bano, K. and Krishnamoorthy, R.U. 1982. Potential of Perionyx excavatus for utilizing organic wastes. Pedobiologia., 23: 419-425.

Karmegam, N. and Daniel, T. 2009. Growth, reproductive biology and life cycle of the vermicomposting earthworm, Perionyx ceylanensis Mich. (Oligochaeta: Megascolecidae). Bioresour. Technol., 100: 4790-4796.

Kuo, S. 1996. Phosphorus. In: Sparks, D.L. (ed.) Methods of Soil Analysis: Part 3 Chemical Methods, SSSA and ASA, W.I., Madison., pp. 869-920.

Lowe, C. and Butt, K.R. 2005. Culture techniques for soil dwelling earthworms: A review. Pedobiologia., 49: 401-413.

Loh, T.C., Lee, Y.C., Liang, J.B. and Tan, D. 2005. Vermicomposting of cattle and goat manures by Eisenia foetida and their growth and reproduction preference. Bioresour. Technol., 96: 111-114.

Reinecke, A., Viljoen, S. and Saayman, R. 1992. The suitability of Eudrilus eugeniae, Perionyx excavatus and Eisenia fetida (Oligochaeta) for vermicomposting in southern Africa in terms of their temperature requirements. Soil Biol. Biochem., 24: 1295-1307.

Rufatto, L.C, Gower, A., Schwambach, J. and Moura, S. 2012. Genus Mikania: chemical composition and phytotherapeutical activity. Revista Brasileira de Farmacognosia., 22(6): 1384-1403.

Shipitalo, M., Protz, R. and Tomlin, A. 1988. Effect of diet on the feeding and casting activity of Lumbricus terrestris and L. rubellus in laboratory culture. Soil Biol. Biochem., 20: 233-237.

Singh, N. 2006. Effect of Initial Substrate $\mathrm{pH}$ on Vermicomposting using Perionyx excavatus (Perrier, 1872). Appl. Ecol. Environ. Rese., 4: 85-97.

Suthar, S. 2006. Potential utilization of guargum industrial waste in vermicompost production. Bioresour. Technol., 97, 2474-2477.

Suthar, S. and Ram, S. 2008. Does substrate quality affect earthworm growth and reproduction patterns in vermicomposting systems? A study using three popular composting earthworms. Int. J. Environ. Waste. Manage., 2: 584-600.

Suthar, S. 2007a. Influence of different food source on growth and reproduction performance of composting epigeics: Eudrilus eugeniae, Perionyx excavatus and Perionyx sansibaricus. Appl. Ecol. Environ. Res., 5(2): 79-92.

Suthar, S. 2007b. Nutrient changes and biodynamics of epigeic earthworm Perionyx excavatus (Perrier) during recycling of some agricultural wastes. Bioresour. Technol., 98: 1608-1614.

Suthar, S. 2008. Microbial and decomposition efficiencies of monoculture and polyculture vermireactors, based on epigeic and anecic earthworms. World J. Microbiol. Biot., 24: 1471-1479.

Suthar, S. 2009. Growth and fecundity of earthworms: Perionyx excavatus and Perionyx sansibaricus in cattle waste solids. The Environmentalist, 29: 78-84.

Suthar, S. and Sharma, P. 2013. Vermicomposting of toxic weed-Lantana camara biomass: Chemical and microbial properties changes and assessment of toxicity of end product using seed bioassay. Ecotox. Environ. Safe., 95: 179-187.

Walkley and Black, I.A. 1934. Determination of organic carbon in soil. Soil Sci., 37: 29-38. 